\title{
THE IMPLEMENTATION OF HIJRAH IN THE SAHABAT HIJRAH MAKASSAR (LIVING SUNNAH STUDY)
}

\author{
Zulkifli Basir ${ }^{1}$ \\ Andi Darussalam ${ }^{2}$ \\ Mahmuddin Mahmuddin ${ }^{3}$ \\ Universitas Islam Negeri Aluddin Makassar ${ }^{1,2,3}$ \\ zulkiflialmandary@gmail.com
}

\begin{abstract}
This research is aimed to discover the meaning of the hijrah hadith; and the implementation of hijrah in the Sahabat Hijrah Makassar Community (the fellow hijrah community Makassar). This is a fieldreference research in which the data is obtained from takhrij hadith, observations and interviews. The researcher then reviews and concludes the result. The hadith used in this research are sahih (valid) and contain versatile contents such as the intentions of hijrah, religious practices equals to hijrah, and the the fail of hijrah. The meaning of hijrah according to the Sahabat Hijrah Makassar Community is divided into two aspects. Those are the understanding of hijrah hadith and the understanding of hijrah out of the hadith context, for example, repentance and identity. The living sunnah is a brand new kind of research that is openly acceptable to the hadith research. The absence of model and analysis for this method is expected to florish the living sunnah studies and discourses in Indonesia. The hijrah movement in Indonesia begins with dakwah by the millennials. Therefore, the government is expected to be aware of this communities.
\end{abstract}

Keywords: Hadith; Hijrah; Living sunnah

\section{INTRODUCTION}

Hijrah (migrate) is a monumental moment in the history of the prophet Muhammad and his companions in the year of 662 from Mecca to Medina ${ }^{1}$. The prophet Muhammad had and his followers had suffered criminal persecution and psychological repression. Humiliation and economical embargo was imposed to them for more than 13 years living in the city of Mecca.

The commitment for hijrah is explained by the prophet Muhammad that whoever intend to do hijrah for wordly purpose or for woman they wanted to propose is basically a hijrah based on self-intention.

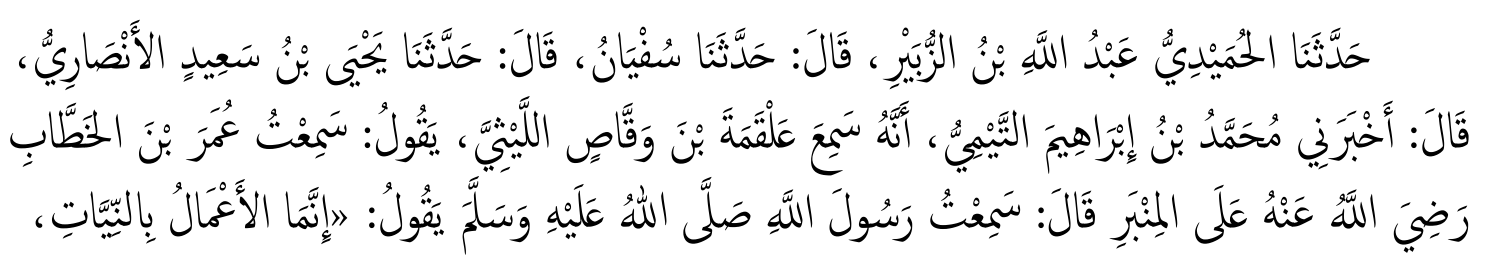

${ }^{1}$ Hans Wehr, diedit JM. Cowan, Arabic-English Dictionary the Hans Wehr Dictionary of Modern Written Arabic (New York: SLS, 1976), p. 1019. 


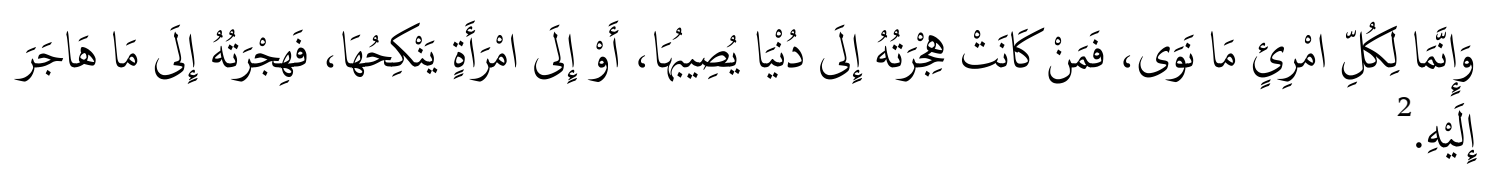

\begin{abstract}
Meaning:
"The Messenger of Allah said, "The reward of deeds depends upon the intention and every person will get the reward according to what he has intended. So, whoever emigrated for Allah and His apostle, then his emigration was for Allah and His apostlee. And whoever emigrated for wordly benefits or for a woman to marry, his emigration was for what he emigrated for." (Sahih al-Bukhari)
\end{abstract}

Al-Zubair bin Bakkar explained the asbab wurud (the background) of the hadith above is that there were an emigrated man with false intention. This man was one of the migration contingent to Madina and his intention was to marry a woman named Ummu Qais. The man was then known as Muhajir Ummu Qais. So, there were a moment when the Prophet Muhammad sat along with all his companion and knew the case. the Prophet then spoke, "The deeds depends on the intention...". 3

The fact above shows that the hijrah intentions to the Prophet followers were various making the Prophet to warn them. Because to Prophet Muhammad, the emigration is not only a territorial migration, but also the alteration of the behavior. Other sources said that hijrah also means abandoning things prohibited by God.

The textual perceive about hijrah is the estabilishment of Sahabat Hijrah Makassar Community. This draws attention from the people and academic students alike. This happens because of the recent trend in community attributed to the term of hijrah. This pehenomenon is quite seen in all kind of community's activities. However, the Sahabat Hijrah Makassar only accomodates this term to the youths which often called "millennials generation".

In this case, the living sunnah research will try to expose how the idea of hijrah pops up in the Sahabat Hijrah Makassar community referrring to the hadith of the Prophet Muhammad about hijrah concept. Eventually, this research is expected to be a brand new insight in the social religious practical atmosphere.

\title{
II. RESEARCH METHOD
}

This is a qualitative research with a field-reference about the implementation of hadith about hijrah within the community of Sahabat Hijrah Makassar. This research is referring to the general hadith mentioning the hijrah term (library research), the research then deviate to the field situation to observe how the contextual hadith is applied to the reality, especially to the Sahabat Hijrah Makassar community. The research is constructed in inductive and comparative anaylses. The researcher is using a multidiciplinary approach such as hadith, phenomenology, and socio-historical approaches. This research is a field-reference through takhrij al-hadith, observation, and interviews.

${ }^{2}$ Muhammad bin 'Ismā‘cil al-Bukhārì, Saḥịh al-Bukhārī, Juz 1 (t.tp: Dār Ṭūq al-Najāh, 1422 H), p. 6.

${ }^{3}$ Ibrahim bin Muhammad al-Dimasyqi, Al-Bayan wa al-Ta'rīf fi Asbāb Wurūd al-Hadìs alSyariff, Juz 1 (Beirut: Dār al-Kitāb al-'Arabi, t.th), p. 4. 


\section{RESEARCH RESULT}

A. The analysis of hijrah based on hadith

1. Hadith mentioning that hijrah depends on the intention

The Prophet Muhammad reiterated that deeds must come with intention and always depends on it, especially about hijrah.

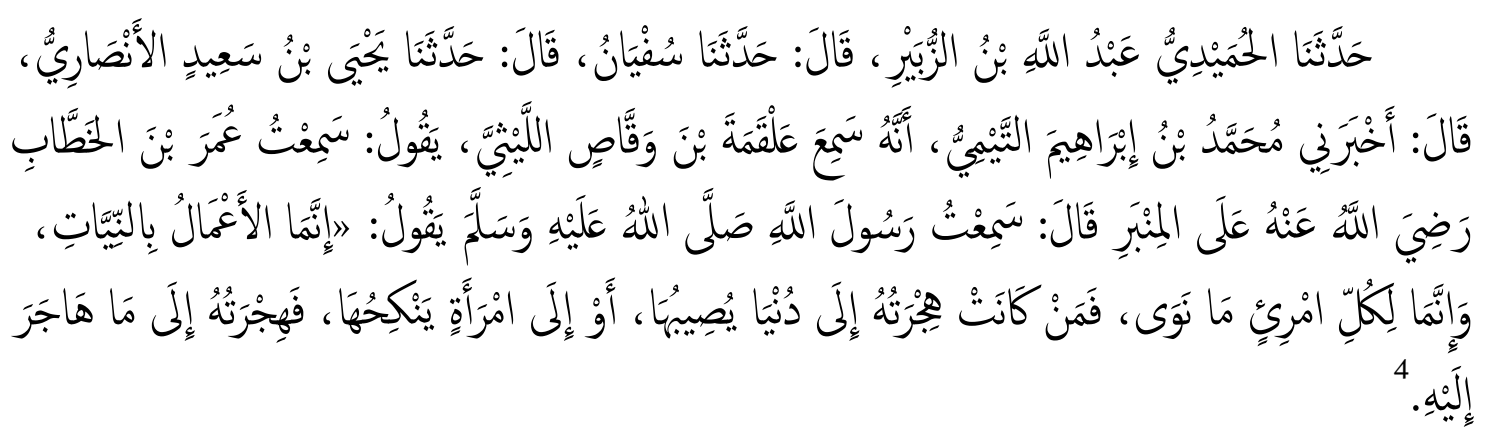

Meaning:

"The Messenger of Allah said, "The reward of deeds depends upon the intention and every person will get the reward according to what he has intended. So, whoever emigrated for Allah and His apostle, then his emigration was for Allah and His apostlee. And whoever emigrated for wordly benefits or for a woman to marry, his emigration was for what he emigrated for." (Sahih al-Bukhari)

The hadith above is excessively notorious among hadith and fiqh studies because al-Bukhari put the hadith at the first chapter. Although, he narrated the same hadith on the other chapter. It is actually a similar hadith, what distinct them is the word niyat. The first chapter is using a plural form, and the other is using a singular word. The differences between them also at the word of "marry". The first hadith use the word yankihuha, and the second one use yatazawwajuha. Ibn Hajar al-Asqalani, however, classified the hadith above to subject about forbidding to do something before it is obvious (bab tark al-hiyat), because a deed that is not based on an apparent intention, hence the deed is void. This is also applied when the deed has not an elucidative law, the intention becomes invalid. ${ }^{5}$ Generally, the main topic of the hadith above is that concerning intentions does not mention anything about hijrah. On the contrary, hijrah is the objective of the intentions.

Imam Abu Ubaidah mentioned that there is no other hadith that contains so much knowledge about intentions as the hadtih above. Imam Ahmad, Imam al-Syafi' $i$, Daruqutni, Abu Daud, Ibnu al-Madini, Ibnu Mahdi and other clerics agreed that that hadith contains one third of the whole knowledge about niyat. The deeds of the humankind is determined by their heart, tongue, and their behavior. ${ }^{6}$

The term that covers this topic in fiqh is "al-umur bi maqassidiha". All the intentions in people's mind to do anything determines the value of their deeds. That is why this term is always mentioned in fiqhiyyah matter.

\footnotetext{
${ }^{4}$ Muhammad bin 'Ismā‘ìl al-Bukhāri, Saḥịh al-Bukhārī, Juz 1 (t.tp: Dār Ṭūq al-Najāh, 1422 H), p. 6.

${ }^{5}$ Lihat: Aḥmad bin 'Ali bin Hajar al-Asqalāni, Fatḥ al-Bārī Syarh Saḥịh al-Bukhārī, Juz 12 (Beirut: Dār al-Ma'rifah, 1379 H), p. 327

${ }^{6}$ Tajuddin 'Abd al-Wahhāb bin 'Ali bin Abduh al-Kaffi al-Subqīi, Al-Asba' wa al-Nazā'ir Juz 1 (Beirut: Dār al-Kutub al-'Ilmiah, 1991), p. 54
} 
Therefore, the there is a reason when the Prophet Muhammad reminded his companions to correct the course of their intentions for hijrah. Because he knew very well about his companions intentions.

2. Hadith about deeds equal to hijrah (abandoning all the disallowed by Allah)

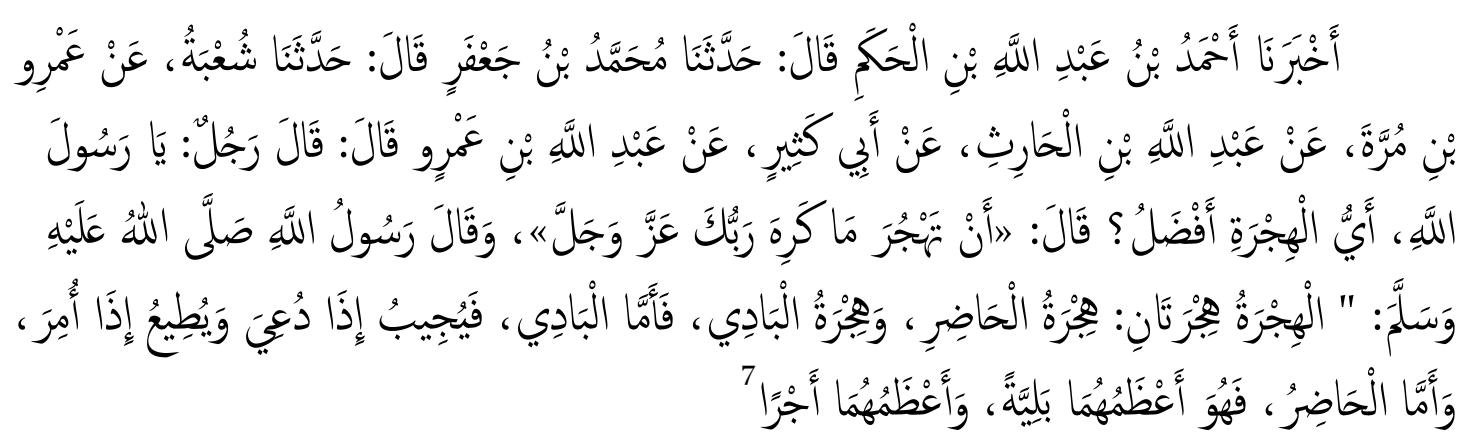

Meaning:

"Abdullah ibn Amr reported: A man asked, "O Messenger of Allah, which emigration is the best?" The Messenger of Allah, peace and blessing be upon him, said, "To emigrate away from that which Allah disapproves. Emigration is of two kinds: the emigrations of the resident and the bedouin. As for the emigration of bedouin, he responds when he is called and obeys when he is commanded. As for the emigration of the resident, its trial is more severe and its reward is greater."

This hadith tells about a man came to the Prophet and asked about hijrah; which are rewarded the most? what al-Qari means here is the primary emigration. To him, hijrah has several kinds: emigrate to Habasyah (Medina) due to prosecution to the companions; emigrate from Mecca to Medina (emigration out of the unbelievers; students who emigrate for the Prophet; and emigration from that which Allah disapproves. The last one is what al-Qari implies above. ${ }^{8}$

The hadith uses the word ma kariha, although other hadith version prefers the word ma harrama which means something Allah forbids ${ }^{9}$. Both has the same meaning, according to al-Qari, which is a suggestion not to do so ${ }^{10}$. What Allah means about undesired things in this hadith is something that makruh.

The deeds equal to hijrah is mentioned in the hadith below, narrated by Ahmad bin Hanbal:

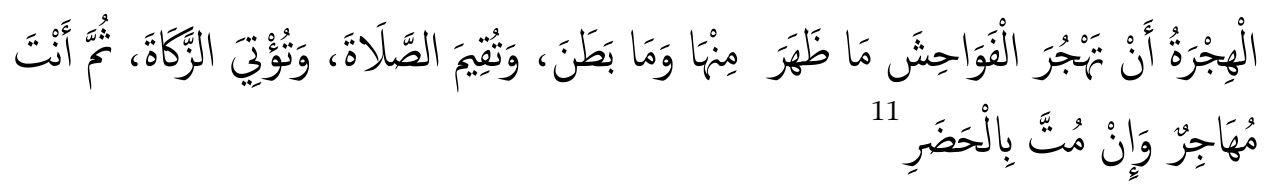
Juz 7, p. 144

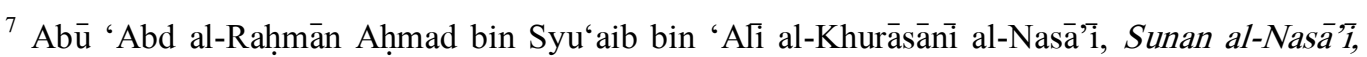

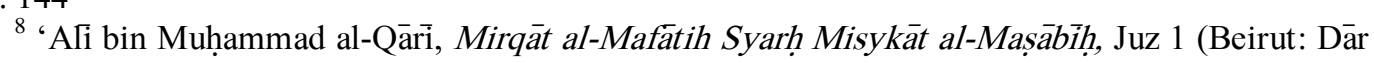
al-Fikr, $1422 \mathrm{H} / 2002 \mathrm{M})$, p. 118

${ }^{9}$ See: Abū Dāud Sulaimān bin al-Asy'as bin Ishāa bin Basyīr al-Azđi al-Sijistān̄ì, Sunan $A b \bar{u}$ Dāud, Juz 2, p. 69.

10 'A

${ }^{11}$ See: Abū 'Abdullah Aḥmad bin Muhammad bin Ḥanbal bin Hilāl bin Asad al-Syaibānī, Musnad Ahmad bin Hanbal, Juz 11, p. 665 
Meaning:

"Immigration is to forsake immorality, visible and invisible, and establish the prayer and you pay zakat, then you are an immigrant even if you die as a settler"

Hadith narrated by Ahmad above shows that hijrah is not only to forsake all the bad things, but also to estabilish the good deeds such as prayers and zakat.

3. Hadith about the void of hijrah

a. No hijrah after the conquest of Makkah

The event of hijrah (emigration) has a deep meaning to the Prophet and his companions. It is a symbol of defending Islam and its struggle. When the conquest of Makkah had taken place, the hijrah will no longer be happening again, the Prophet said. In this case, hijrah about something positive apart from jihad. Below is the hadith from the Prophet narrated by al-Bukhari:

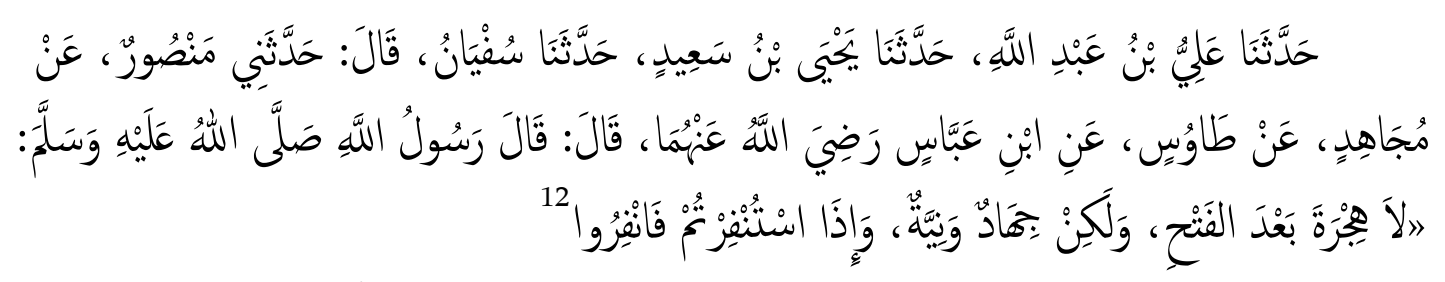

Meaning:

"Allah's Messenger (said, "There is no Hijra (i.e. migration) (from Mecca to Medina) after the Conquest (of Mecca), but Jihad and good intention remain; and if you are called (by the Muslim ruler) for fighting, go forth immediately."

Ibnu Hajar explains that the end of hijrah mentioned in the hadith above is that of emigration leaving the city of Madinah. The other form of hijrah is still available such as leaving for taking education, leaving dar al-kufr, leaving to protect our belief, and so on. ${ }^{13}$

Abdullah Azzam also explains that the Prophet chose to declare the end of hijrah from Makkah to Madinah because the conquest of Makkah had been promised in the year 8 of Islamic calendar. Those who have emigrated prior to the event of Fath Makkah (the conquest of Makkah) were honoured as the Muhajirin, and those who emigrated afer the historic event would have still embedded the honorary title with the absence of hijrah reward. To achieve it, the Prophet told the companions to do jihad to do the good deeds. The hadith above is also a proof that hijrah will always continue until the end of the world. ${ }^{14}$

b. Hijrah would never be void until the sun sets from the west

The previous hadith is paradoxical to other valid hadith. The statement said that the hijrah will never end until the sun sets from the west, which is:

${ }^{12}$ Muhammad bin 'Ismāđāil al-Bukhārī, Sahịịh al-Bukhārīi, Juz 4, p. 15

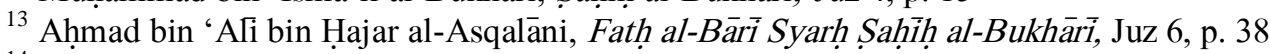

${ }^{14}$ Abdullah Azzam, Hijrah dan I’dad, terj. Abdurrahman (Solo: Pustaka al-Alaq, 2001), p. 145- 


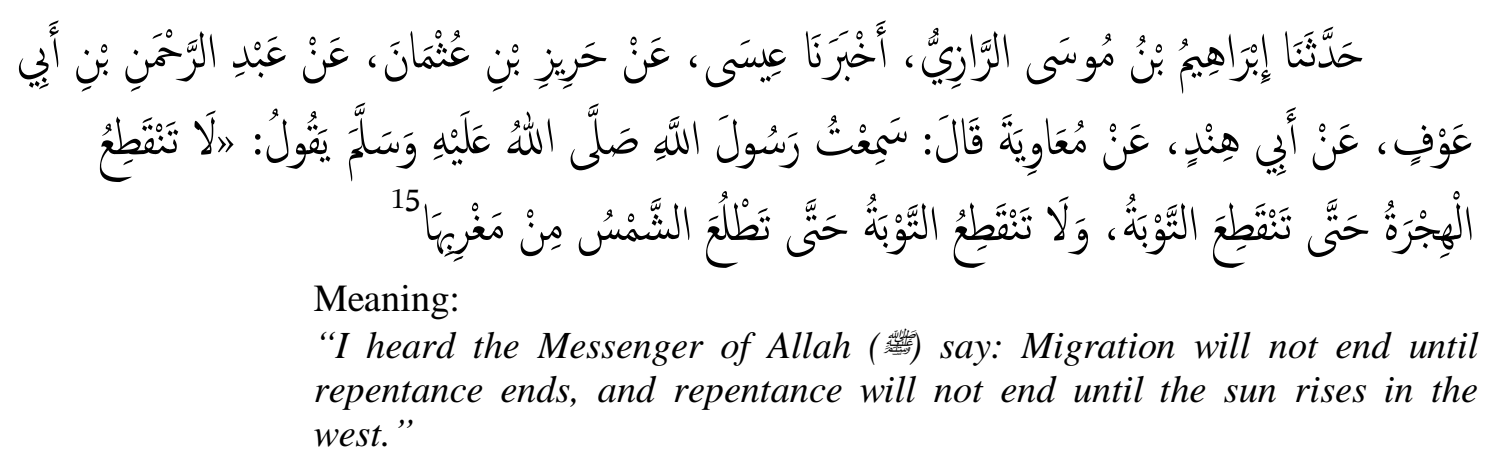

Both the hadith above and the previous one are quite digestible; what the prophet means in the sentence No more hijrah after the conquest of Makkah is a hijrah from Makkah to Madinah. While in the other hadith he stated that the hijrah will never ends to those who moved from dar al-kufr to dar al-Islam to save their faith."

According to that dialectical, al-Nawawi stressed that the subtitute deeds after physical hijrah is jihad and other fine deeds. ${ }^{16}$ Experts say that the urgency of hijrah based on geographical point of view is that those who lived under the nonIslamic government. Among these experts are Ibn al-Arabi, Ibn Hajar, al-Tayyibi and others.

B. The Understanding of The Sahabat Hijrah Makassar Community About Hijrah and its Implementation

Sahabat Hijrah Makassar community is one of the communities in Makassar to enhance the youths in Makassar to visit mosque for their spiritual needs. Sahabat Hijrah Makassar (which later will be called SHM), which is administered in Project Dakwah Centre office was estabilished in early 2017 by young people with various background. Prior to the founding, they were quite non religious folks, then decided to join recitement group and feel comfortable with that. From that point, they decided to estabilish their own community with hijrah as its background.

The community is named Sahabat Hijrah Makassar because they realized that hijrah does not come by itself, it takes some people to make someone to do hijrah. A best friend, for example. Therefore, the community picked the name Sahabat Hijrah Makassar with Ilham Anugrah as the leader and Yordan as its secretary at that time. There were four divisions in SHM, they are dakwah division, sport division, equipment division, and media division. These divisions are ran by 14 board members, managing the uncountable members, because SHM does not limit their members.

The community began limitting its discussion program and more focus on dakwah ever since Arkam took the leadership. This new program wrapped as the Dakwah Movement. Others called it hijrah booster.

The mission of the SHM community spread not only within the internal, but also delivered on various social media. They have many followers, especially from Makassar and other cities. Their social media are Instagram (@sahabathijrahmks), Facebook (sahabathijrahmakassar), and Youtube channel (Sahabat Hijrah Makassar). ${ }^{17}$

In living sunnah study, as explained by Saifuddin Zuhri, these religious narration in which the source is anonymous are now common in society, especially in Indonesia. But, Juz 3, p. 3

${ }^{15}$ Abū Dāud Sulaimān bin al-Asy“as̀ bin Ishāq bin Basyīir al-Azdì al-Sijistānī, Sunan Abū Dāud,

${ }^{16}$ Muhammad bin 'Ali bin Muhammad bin Abdillah al-Syaukānī, Nail al-Auțār, Juz 8 (Ed.I; Egypt: Dar al-Asr, 1413 H/ 1993 M), p. 32

${ }^{17}$ Muh. Akram, Leader of Sahabat Hijrah Makassar, interview, Makassar, 8 January 2020 
obviously, this is not far from the maun source of Islam; Quran and Hadith. This religious pratical change is caused by local influence and the people who has the religious aouthority become the transmission subject to the topic of the community discussion both textually and verbally. ${ }^{18}$

The speaker, or the "agent" according to Saifuddin, is muballigh who is an expert in youth psychology in dakwah matter. According to the researchers' observation, these speakers are relatively young.

The next element to be discussed is the recipient of the agents. In this case, all the active members of SHM and the board members. The discussion is delivered via gathering, which they use to call it hijrah booster.

The researchers observed that the understanding of hijrah according to SHM divided into two aspects; the understanding about hijrah based on hadith and the understanding of hijrah outside of the hadith context.

1. Understanding of hadith about hijrah

Based on the SHM visions, the main source of their subject is Quran and hadith:

a. Vision: a house for hijrah

b. Mission:

1) Promoting young people to do hijrah

2) Shaping Islamic character to the youths

3) Preserving brotherhood among muslim youths

4) Making Quran and hadith as the way of life

5) Uniting creative youths in the spirit of dakwah

These missions can be understood in two perspectives, whether from Quran and hadith point of view about hijrah, or out of the context of hadith that is still entangeled with hijrah.

In understanding hadith about hijrah, SHM quoted few hadith and Quran verses that is closely related to hijrah, which is hadith about it and deeds equivalent to the hijrah itself.

2. Understanding of hijrah outside of the context of hadith

Within internal of the SHM community, the term of hijrah does not always refer to the textual preferences such as that of the hadith, but also outside of it. This can be seen from the materials delivered the in community. The preachers often times delivered dakwah theme not far from the subject of hijrah.

For example, a call for atonement. It is part of hijrah. Islahuddin Ramadhan, in his "hijrah booster" discourse cited one of the Prophet hadith: ${ }^{19}$

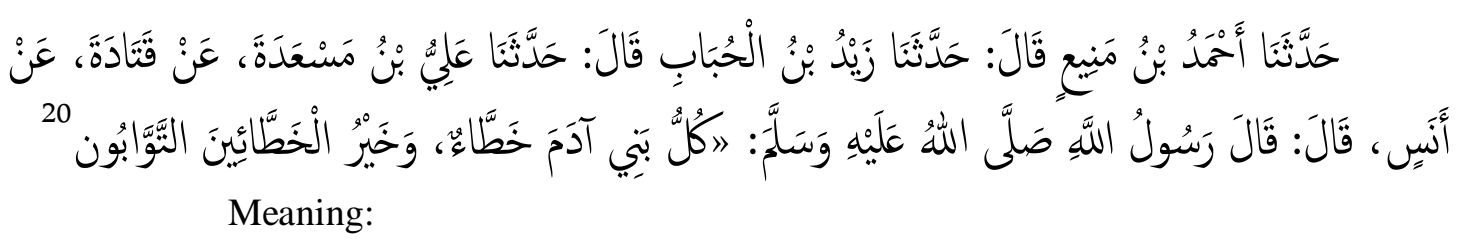

${ }^{18}$ See, Saifuddin Zuhri Qudsy, "Living Hadis: Genealogi, Teori, Dan Aplikasi”, Living Hadis, Vol. 1, No. 1, May (2016), p. 186

${ }^{19}$ Youtube Sahabat Hijrah Makassar

${ }^{20}$ Ibnu Majah Abu 'Abdullah Muhammad bin Yazid al-Qazwaini, Sunan Ibnu Majah, Juz 2

(t.tp: Dar Ihya' al-Kutub al-'Arabiah, t.th), p. 1420 


\section{The Implementation of Hijrah in \\ The Sahabat Hijrah Makassar (Living Sunnah Study)}

"Every son of Adam commits sin, and the best of those who commit sin are those who repent. (Narrated by Ibnu Majah)"

Similar concept is also delivered by Akram (leader) that atonement is a process of hijrah where you regret all the wrongdoings that against religious values and proceed to commit well deeds immediately. ${ }^{21}$ Hijrah is like a buliding, and repent is the content of the building.

The researchers believe that the understanding of hijrah is about identity; how we look, dress, and how we speak. Akram admits that when he began hijrah, he committed to abolish all the sinful deeds instead of changing his looks. The alteration of the identity, according to him, was not done accidently, but rather was done through learning step by step. ${ }^{22}$

To Akram, identity is a process. People would slowoly changing their appearance as they learn to understand hijrah. He believes that changing appearances without actually knowing the "reason" behind the change is dangerous.

The understanding of hijrah outside of the textual hadith is shown in the social media of the SHM community. In its Facebook and Instagram account, it often shares Islamic quotes that is unrelated to hijrah.

Hijrah, which is essentially understood from hadith or from the concept apart from it, is enwrapped in hijrah booster and dirosah (studying):

a. Hijrah booster is one of the best method to help people for hijrah to become a better person. The subject of the materials can be selected applicable to the current issue and is broadcasted on Facebook live and Instagram live.

b. Dirosah and tahsin, is a special training to teach adult about Quran. It is also a program in the community to teach all the members, and continued to the tahsin program.

The community is not only active on studying together and other social movement, but also hijrah is applied in the daily routine to each of its member to become a better person.

\section{CONCLUSION}

Based on the explanations above, it can be concluded that hadith about hijrah in this research is genuine and various meaning, such as hadith about hijrah depending on intentions, deeds that equal to hijrah, and the cause of the void of hijrah. As an object of research, the researcher obtain new insight about religious practices based on hadith interpretation about hijrah. This interpretation process came into reality by those who involved in, like so called "agent". In this case, muballigh and dai have the role as the agent who expertized the psychology of the young people and their dakwah needs. The understanding about hijrah according to the Sahabat Hijrah Makassar community is divided into two aspects. First, the understanding according to the hadith about hijrah, and second, the understanding from the outside context of hadith such as atonement and identity.

\footnotetext{
${ }^{21}$ Muh. Akram, Leader of Sahabat Hijrah Makassar, interview, Makassar, 8 January 2020

${ }^{22}$ One of the theme in hijrah booster is Asyiknya nyunnah (Sunnah is fun), inspired from the story of changing identity
} 


\section{REFERENCE}

Annisa Novia Sari dan Adi Bayu Mahadian, Pelaku Komunikasi Hijrah: Studi Fenomenologi Pelaku Hijrah dalam Shift Gerakan Pemuda Hijrah di Kota Bandung, Jurnal Linimasa, Vol. 1, No. 1, January (2018), p. 1.

Al-Asqalāni, Aḥmad bin 'A זi bin Ḥajar. Fatḥ al-Bārī Syarh Saḥị̣ al-Bukhārī, Beirut: Dār al-Ma'rifah, $1379 \mathrm{H}$

Azzam, Abdullah. Hijrah dan I'dad, terj. Abdurrahman, Solo: Pustaka al-Alaq, 2001.

Al-Bukhārì, Muhammad bin 'Ismā'îl. Saḥịh al-Bukhārì, t.tp: Dār Ṭūq al-Najāh, 1422 $\mathrm{H}$.

Al-Dimasyqi, Ibrahim bin Muhammad. Al-Bayan wa al-Ta'rif fi Asbāb Wurūd alHadis al-Syariff, Beirut: Dār al-Kitāb al-'Arabi, t.th.

Iqbal, Muhammad. Kamus Dasar Islam, ( Jakarta: Inovasi, 2001), p. 108.

Iswan, Desi Triana. "Makassar Berhijrah Diikuti Ribuan Jamaah di al Markaz" Tribun-Timur.com, 11 March 2019, makassar.tribunnews.com/amp/2019/03/11/Makassar-berhijrah-hadirkanribuan-jamaah-di-almarkaz. (2 December 2019)

Jazuli, Ahzami Samiun. Hijrah dalam Pandangan al-Qur'an, Jakarta: Gema Insani, 2006.

Muh. Akram, Leader of Sahabat Hijrah Makassar, interview, Makassar, 8 January 2020.

Al-Qārì, 'Ali bin Muhammad. Mirqāat al-Mafătih Syarḥ Misykāt al-Maṣābīḥ, Beirut: Dār al-Fikr, 1422 H/2002 M.

Al-Qazwaini, Ibnu Majah Abu 'Abdullah Muhammad bin Yazid. Sunan Ibnu Majah, Juz 2 (t.tp: Dar Ihya' al-Kutub al-'Arabiah, t.th.

Qudsy, Saifuddin Zuhri. "Living Hadis: Genealogi, Teori, Dan Aplikasi", Living Hadis, Vol. 1, No. 1, May, 2016.

Shihab, M. Quraish. Tafsir Al-Misbah: Pesan, Kesan dan Keserasian al-Qur'an Jakarta: Lentera Hati, 2004.

Suarni, Sejarah Hijrah dalam Perspektif al-Qur'an, Al-Mu'ashirah, Vol. 13, No. 2, July, 2016.

Al-Subqī, Tajuddin 'Abd al-Wahhāb bin 'Ali bin Abduh al-Kaffi. Al-Asba' wa alNazā'ir, Beirut: Dār al-Kutub al-'Ilmiah, 1991.

Suci Wahyuni Fajriani dan Yogi Suprayogi Sugandi, Hijrah Islami Milenial Berdasarkan Paradigma Berorientasi Identitas, Sosioglobal : Jurnal Pemikiran dan Penelitian Sosiologi, Vol. 3, No. 2, June, 2019.

Syarif, Studi Living Qur'an-Hadis di Kalangan Pemuda Hijrah Shift di Kota Bandung: dari Resepsi hingga Konstruksi Identitas Kolektif,, Tesis Yogyakarta: UIN Sunan Kalijaga, 2019. 
Al-Syaukānī, Muhammad bin 'Ali bin Muhammad bin Abdillah. Nail al-Auțār, Juz 8 (Ed.I; Egypt: Dar al-Asr, 1413 H/ 1993 M), p. 32.

Wehr, Hans. diedit JM. Cowan, Arabic-English Dictionary the Hans Wehr Dictionary of Modern Written Arabic. New York: SLS, 1976.

Youtube Sahabat Hijrah Makassar. 